\title{
Women Participation in Livestock Raising and Household Managemnt In Rural Communities of Nafada, Semi-Arid Region of Northeastern Nigeria.
}

\author{
Yakubu Dan \\ Department of Geography, \\ Gombe State University, Gombe, Nigeria. \\ Idoma Kim \\ Department of Geography, \\ Gombe State University, Gombe, Nigeria.
}

\begin{abstract}
This study was carried out to examine women's participation in livestock raising in rural communities of Nafada, semi-arid region of Northeastern Nigeria. Thirteen villages were purposively sampled, and 10 women respondents were randomly selected from each village. Standardized interview schedule was adopted in the collection of information from the sampled respondents and analyzed using descriptive statistics and Pearson Product Moment Correlation. The results disclosed that approximately half $(45 \%)$ of the respondents raised goats and sheep and $100 \%$ were involved regularly in cleaning of animal sheds, watering and grazing of animals. In addition, washing of clothes, food preparation, cleaning of the house, looking after all family members, child/family health care, preparing beverages and cleaning up after meals ranked highest among household activities undertaken by women. Major challenges of livestock raising, and household management were low innovation (ranked 1), rustling (ranked 2), ranching (ranked 2) and health of animals (ranked 2). Others included child/family care (ranked 1), food (ranked 1), fuel wood collection (ranked 3) and absence of funding from government agents. The correlation results revealed that family size and education of respondents were significant factors influencing the extent of women's participation in livestock raising in the study area. Therefore, carefully targeted women-focused programmes on livestock farming, intensive adult education and improved agricultural extension/ veterinary services among others are crucial to improving women's participation in livestock production in Nafada LGA.
\end{abstract}

Keywords: Household Management, Livestock Raising, Nafada, Participation, Rural Communities, Women.

\section{INTRODUCTION}

Without doubt, the women folk play a prime role in the agricultural and rural economies in developing countries all over the world (Dawit, Tadesse, Ahmed, and Minilek, 2012). These roles are not only dominant and prominent but also essential in curbing the challenges of agricultural production and development (Ogunlela and Mukhtar, 2009). However, in many parts of the world, women's roles in agriculture differ significantly between and within regions owing to economic and social forces transforming the agricultural sector. In rural communities of Nigeria, specifically the northern states, women play significant roles in both livestock activities and household management aside from crop farming activities. Their activities typically include producing agricultural crops, tending animals, processing and preparing food, working for wages in agricultural or other rural enterprises, collecting fuel and water, engaging 
in trade and marketing, caring for family members and maintaining their homes (Abdulhameed and Onuk, 2016; Arshad, Muhammad, Mahmood and Khalid, 2010).

Extant studies such as Mulugeta and Amsalu (2014) on women's role and their decision making in livestock and household management in Amhara region of Ethiopia using questionnaire and focus group discussion (FGD) showed that majority (98\%) of the women participated regularly in livestock activities and household management but had less involvement in decision making.

Similarly, Amin, Ali, Ahmad, and Zafar, (2010) examined the role of rural women in livestock production in Ter.Faisalabab in Parkistan. A multi-stage random sampling method was used to collect data from 8 villages regarding livestock production activities. Most of the families (70.6\%) were living in the joint family system. Out of the total of 768 respondents, more number of wives $(37.5 \%)$ participated in livestock production activities as compared to the husbands $(17 \%)$.

Ayoade, Ibrahim and Ibrahim, (2009) analysed women's involvement in livestock production in Lafia area of Nasarawa State, Nigeria. Simple random sampling was used to select 90 women livestock producers. Simple Descriptive Statistics, Participation Index and Multiple Regression Analysis were used to analyse the data. Results indicated that women always participated in the feeding of animals (mean=2.94), cleaning of pens and cages (mean=2.90), provision of water (mean=2.90). One major constraints faced was the dominance by their spouses in management and decision making.

The foregoing review implied that women played dominant role in livestock production in Africa and beyond. However, research has consistently shown that the economic contributions by women have not only been misinterpreted and unacknowledged but very little has been written and known about what women do in diverse sectors of the economy and particularly in agricultural sector (IFAD, 2007;World Bank, 2003 ). Inaccurate and misleading statistics on female labor participation (even in official reports and documents) in livestock (and agriculture) often leads to gross underestimations of the magnitude and importance of women's work in this sector. This has stifled their ability to gain access to government and other development actors for necessary support.

In view of the above, the need to analyze the participation of women in livestock raising in rural communities of Nafada LGA of Gombe State, where significant involvement of women in livestock production is observed becomes imperative. The objectives of this study were to:

I. Examine the extent of the role of women in livestock raising in Nafada rural communities.

II. Analyze the uses of income generated from livestock raising by the women.

III. Identify challenges women face in livestock raising in the study area

IV. Investigate challenges women face in household management

\section{MATERIALS AND METHODS}

\section{Study area}

The study was conducted in the rural areas of Nafada LGA in the Sahel Savanna of North Eastern Nigeria. The study area is located between latitude $11^{\circ} 0^{\prime} 00^{\prime \prime}-11^{0} 33^{\prime} 00^{\prime \prime} \mathrm{N}$ and longitude $11^{0} 15^{\prime} 00^{\prime \prime}-11^{0} 25^{\prime} 00^{\prime \prime} \mathrm{E}$ (Figure 1). The 2018 projected figures of 2006 population census of the study area is about 199,257 persons per square Kilometers. It occupies a total land area of about $1766.80 \mathrm{Km}^{2}$. It is about $97.88 \mathrm{Km}$ away from Gombe, the state 
Headquarters, it is bounded to the North East by Yobe State and to the North West by Bauchi State.

Nafada Local Government Area is located within the Sudan Savanna climate Zone. The climate is characterized by two distinct seasons; the rainy season, which starts around late May and ends in October, whereas the dry season begins from November and ends in April. The presence of the Sahara Desert in the Northern hemisphere brings about dusty winds characterized by cold dry air known as "Harmattan". The mean annual rainfall is about $870 \mathrm{~mm}$ to $1000 \mathrm{~mm}$, while the mean temperature is averagely warm and hot throughout the year at about $27^{\circ} \mathrm{C}$ a minimum temperature of $19^{\circ} \mathrm{C}$ (Aminu, 2007). The soils consist of clayish materials called "Vertisols" and characterized by vast number of trees such as Baobab, Acacia, Tamarine trees etc. Farming, fishing and livestock keeping are the major occupations of the people of the study area. Irrigation is heavily practiced along the bank of the River Gongola (Aminu, 2007)

\section{Figure1: Study Area}

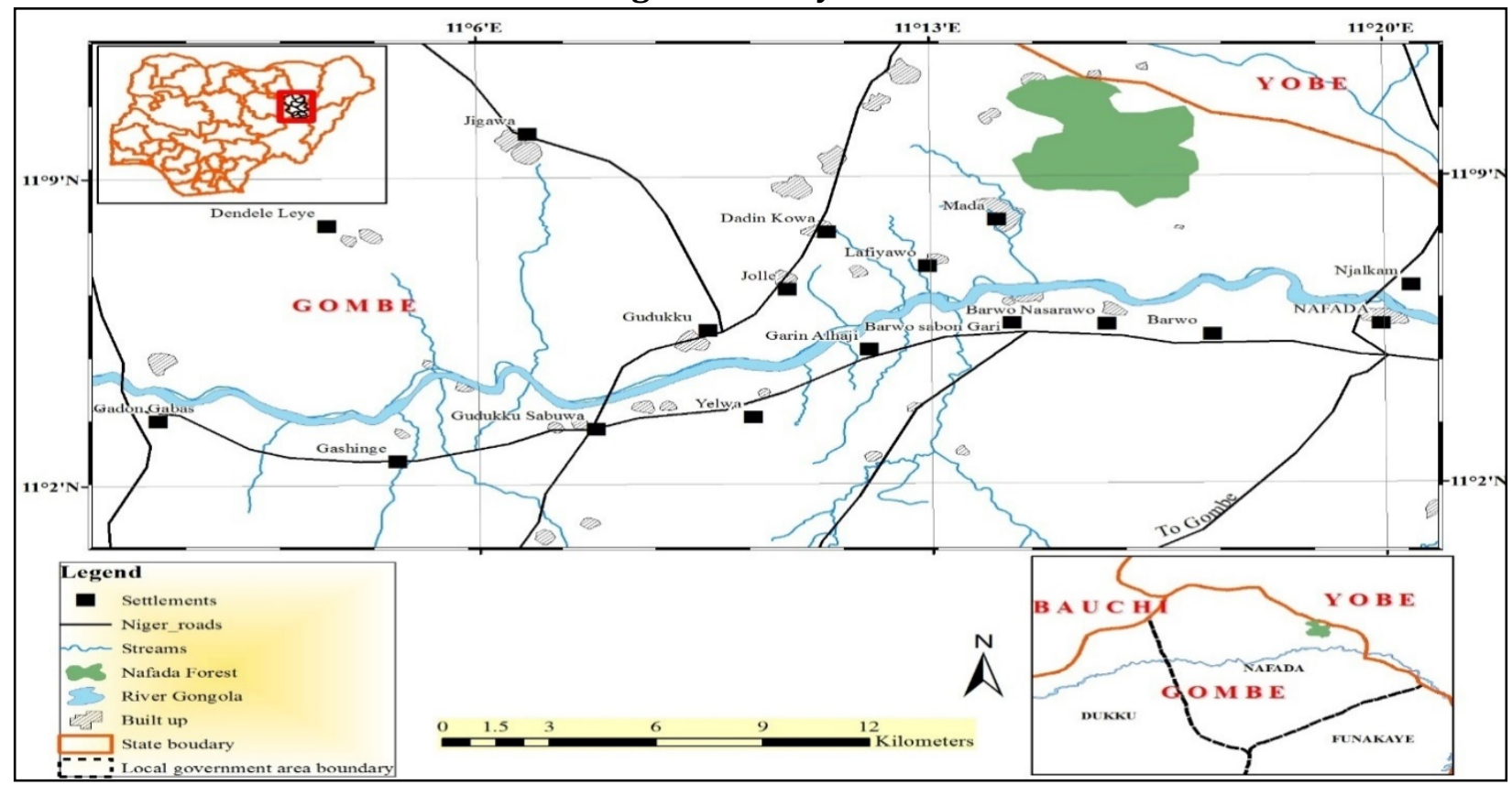

Source: GIS and Remote Sensing Unit, Gombe State University, Gombe.

\section{Sampling technique and sampling size}

Purposive sampling technique was adopted in the selection of thirteen rural communities based on the information gathered via reconnaissance survey on the volume of livestock production and physical accessibility. Subsequently, households with women engaged in raising small ruminants of goats in each of the thirteen villages were identified. The population of the study area was based on 2018 projected figures of 1991 National Population Census .The results of the 1991 census were used for the projection because the results of the 2006 census do not contain community level data. The projection of sampled localities' population was based on Gombe State population growth rate of 3.05\% using the formula: $\mathbf{P}_{\mathbf{t}+\mathbf{n}}=\mathbf{P}_{\mathbf{t}} \mathbf{e}^{\mathbf{r}^{*} \mathbf{n}}, \mathbf{W h e r e}$, $\mathrm{P}_{\mathrm{t}+\mathrm{n}}=$ Future population (2018), $\mathrm{P}_{\mathrm{t}}=$ Base year (1991), $\mathrm{e}=$ exponential, $\mathrm{r}=$ Growth rate (3.2\%), $\mathrm{n}$ =Interval between future population and base year population (2018-1991=27years). This is shown in Table 1. To obtain the sample size for the study, Yamane (1967) method of sample size determination was employed. Based on this, 95\% confidence level and error limit of 10\% were adopted. Yamane (1967) formula is depicted as $\mathrm{n}=\frac{N}{1+N\left(e^{2}\right)}$ where $\mathrm{n}=$ required sample, $e^{2}=$ error limit ( $0.1 \mathrm{in}$ this case), $\mathrm{N}=$ Population size. Hence, a sample size of 100 was used for the study. To account for possible misplacement and destruction, the number of subjects was 
increased to 130 (Table 1). Thereafter, 130 female respondents were drawn as sample size for the study. However, 123 copies of questionnaire were retrieved out of 130 administered. This gave a response rate of $94.62 \%$. Information elicited from the respondents was based on issues pertaining to the extent of gender involvement in raising small ruminants as well as engagement in household management.

Table 1: Sample size and allotment of questionnaire

\begin{tabular}{lllll}
\hline S/No. & Selected Communities & $1991(\mathrm{NPC})$ & $\begin{array}{l}\text { 2018 Projected } \\
\text { Population }\end{array}$ & $\begin{array}{l}\text { Proportion of } \\
\text { questionnaire }\end{array}$ \\
\hline $\mathbf{1}$ & Nafada & $\mathbf{8 6 9 4}$ & $\mathbf{2 0 5 4 5}$ & $\mathbf{5 8}$ \\
$\mathbf{2}$ & Barwowinde & $\mathbf{1 8 0 0}$ & $\mathbf{4 2 5 4}$ & $\mathbf{1 2}$ \\
3 & BarwoNassarawo & $\mathbf{2 7 8 3}$ & $\mathbf{6 5 7 7}$ & $\mathbf{1 7}$ \\
$\mathbf{4}$ & BarwoSabongari & $\mathbf{4 1 8}$ & $\mathbf{9 8 8}$ & $\mathbf{3}$ \\
$\mathbf{5}$ & GarinAlhaji & $\mathbf{5 6 2}$ & $\mathbf{1 3 2 8}$ & $\mathbf{4}$ \\
$\mathbf{6}$ & Yelwa & $\mathbf{6 2 5}$ & $\mathbf{1 4 7 7}$ & $\mathbf{4}$ \\
7 & Njalkam & $\mathbf{1 0 2 0}$ & $\mathbf{2 4 1 0}$ & $\mathbf{7}$ \\
$\mathbf{8}$ & Mada & $\mathbf{4 8 4}$ & $\mathbf{1 1 4 4}$ & $\mathbf{3}$ \\
$\mathbf{9}$ & Lafiyawo & $\mathbf{3 5 2}$ & $\mathbf{8 3 2}$ & $\mathbf{2}$ \\
$\mathbf{1 0}$ & Gudukku & $\mathbf{1 1 6 8}$ & $\mathbf{2 7 6 0}$ & $\mathbf{8}$ \\
$\mathbf{1 1}$ & Dadin Kowa & $\mathbf{7 2 1}$ & $\mathbf{1 7 0 4}$ & $\mathbf{6}$ \\
$\mathbf{1 2}$ & GudukkuSabuwa & $\mathbf{9 4}$ & $\mathbf{2 2 2}$ & $\mathbf{1}$ \\
$\mathbf{1 3}$ & Jolle & $\mathbf{7 1 5}$ & $\mathbf{1 6 9 0}$ & $\mathbf{5}$ \\
Total & & $\mathbf{1 9 4 3 6}$ & $\mathbf{4 5 9 3 1}$ & $\mathbf{1 3 0}$ \\
\hline
\end{tabular}

\section{Data analysis}

Simple Descriptive Statistics such as frequency counts and percentages were used to satisfy objectives 2, 3 and 4. A Participation index was used to achieve objective 1 . The index was constructed using a 3-point continuum. The 3 points scales were weighted in order of importance from; regular $=2$, occasionally $=1$, and not all $=0$. The respondents were asked to indicate their level of participation in the activities involved in Livestock production. Pearson product moment correlation was employed in analyzing the relationship between social variables and involvement of rural women in livestock and household activities.

\section{RESULTS AND DISCUSSION}

\section{Socio-economic characteristics of respondents}

The socio-economic characteristics of the respondents for various variables are presented in Table 1. 
Table 1: Socio-Economic and Demographic Characteristics of the Respondents $(n=123)$

\begin{tabular}{|c|c|c|}
\hline Characteristics & Number & Percentage \\
\hline \multicolumn{3}{|l|}{ Age } \\
\hline Below 20 & 10 & 8.1 \\
\hline $21-30$ & 59 & 48.0 \\
\hline $31-40$ & 30 & 24.4 \\
\hline $41-50$ & 13 & 10.6 \\
\hline Above 50 & 11 & 8.9 \\
\hline \multicolumn{3}{|l|}{ Education } \\
\hline Primary & 16 & 13.0 \\
\hline Secondary & 16 & 13.0 \\
\hline Qur'anic & 91 & 74.0 \\
\hline \multicolumn{3}{|l|}{ Marital Status } \\
\hline Married & 122 & 99.2 \\
\hline Widow & 1 & .8 \\
\hline \multicolumn{3}{|l|}{ Marital Union } \\
\hline Polygamy & 56 & 45.5 \\
\hline Monogamy & 67 & 54.5 \\
\hline \multicolumn{3}{|l|}{ Household Size } \\
\hline Below 5 & 25 & 20.3 \\
\hline $6-10$ & 59 & 48.0 \\
\hline $11-15$ & 30 & 24.4 \\
\hline $16-20$ & 6 & 4.9 \\
\hline Above 20 & 3 & 2.4 \\
\hline \multicolumn{3}{|l|}{ Joint Family Responsibility } \\
\hline Yes & 120 & 97.6 \\
\hline No & 3 & 2.4 \\
\hline \multicolumn{3}{|l|}{ Occupation } \\
\hline House wife, farming and civil servant & 3 & 2.4 \\
\hline House wife, farming and petty trading & 13 & 10.6 \\
\hline House wife only & 3 & 2.4 \\
\hline House wife and raising animal & 64 & 52.0 \\
\hline House wife and farming & 1 & .8 \\
\hline $\begin{array}{l}\text { House wife, raising animals and petty } \\
\text { trading }\end{array}$ & 36 & 29.3 \\
\hline House and Tailoring & 3 & 2.4 \\
\hline \multicolumn{3}{|l|}{ Income } \\
\hline Below 10000 & 4 & 3.3 \\
\hline $10000-30000$ & 57 & 46.3 \\
\hline $30100-50000$ & 48 & 39.0 \\
\hline $50100-70000$ & 11 & 8.9 \\
\hline $70100-90000$ & 3 & 2.4 \\
\hline
\end{tabular}

Source: Fieldwork, 2018

The majority (72.4\%) of the respondents were in the age bracket of 21 to 40 years implying that they are in active productive age with ample potentials of contributing and participating in the economic activities to serve their families and the nation at large. Aging is associated with a progressive decrement in various components of physical work capacity, including aerobic power and capacity, muscular strength and endurance, and the tolerance of thermal stress (Shephard, 1999). Most of the respondents (74\%) had qur'anic education, while the residual proportion accounted for holders of primary and secondary education. This indicates that almost three-quarter of the women in livestock production did not have formal education. This finding is consistent with those of Ayoade, Ibrahim and Ibrahim (2009) who found that majority of the women in livestock production in Lafia had no formal education. Low education 
of women livestock raisers could have negative influence on their extent of involvement in livestock production. The result also showed that all the women in livestock production in the study area were married apart from one respondent who was widowed. The marital status of a woman matters in determining her level of participation in the income generating activities. For instance, social and economic status of the widowed women coupled with the family's headship status put them in a condition where they must work hard to meet the subsistence needs of the family (Tusawar, 2013). It was also reported that $72.4 \%$ of the respondents had between 6 and 15 household sizes. This large family size has positive consequence for livestock management and household activities in view of the high labour demands of these activities. However, Azid, Aslam, and Chaudhary (2001) asserted that the families with large sizes, increase women's responsibilities as housewives and mothers so affect and limit their number of hours' allocation to economic activities. Table 1 also disclosed that joint family responsibility predominates in the study area based on the assertion of $97 \%$ of the respondents. A study conducted by Amin, Ali, Ahmad and Zafar (2010) regarding the family system, which revealed that in Punjab, most of the respondents (70.6\%) were living in the joint family system is in harmony with the above-mentioned results. Data on occupation indicated that a greater proportion $(52 \%)$ of the respondents who are full time house wives also engaged in raising of animals. Nearly half (46.3\%) of the women involved in raising of animals earned between N10000 - $\$ 30000$ monthly. With this scenario, we can infer that most of the women involved in livestock production in the study area are of low economic base, which accounted for their greater involvement in livestock raising. Notably, income status of household influences women's level of contribution to family upkeep. Therefore, Shafiq, (2008) maintained that women from poorer families tend to play a greater role in livestock production than women from relatively well-off households.

\section{Livestock breeds and holdings}

Table 2 expresses information on the kind or species of herds and birds raised along with the numbers owned by respondents in study. It has disclosed that $45 \%$ i.e. almost half of the respondents raised goats and sheep. Majority 67\%, 45\% and 7\% of respondents who raised goats, sheep and cows respectively had livestock sizes of between 11 and 20. Herd size matters in determining women's level of participation in livestock management activities. For managing small, medium and large sized herd, a woman's time allocations toward livestock management activities will respectively increase. This agrees with the works of Afridi, Ishaq and Ahmad, (2009) who affirmed that while managing small, medium and large sized herd, women's time allocations toward livestock management activities were 2.76 hours, 4.12 hours and 3.23 hours respectively. In terms of birds, Table 2 showed that a greater percentage (58\%) i.e. virtually three-fifth of the respondents who engaged in poultry raised chickens. Majority $42 \%$ and $8 \%$ of poultry farmers had between 21 to 30 chickens and guinea fowls respectively, whereas $11 \%$ of the participants had between 10 to 20 ducks. The foregoing analyses established that goats, sheep and chickens were the dominant livestock species raised by women in Nafada Local Government Area. Ayoade, Ibrahim and Ibrahim (2009) and Beth (2001) statement that women claimed smaller species such as poultry, goat, and sheep rather than cattle, camel, or buffalo since the initial cost of investment are lower and hence cheaper to raise validate this outcome. In addition, the plausible reasons for the high proportion of goats and chickens reared in the study area could be their resistance to diseases and adaptability to the climate variability of the study area 
Table 2: Livestock Breeds and Holdings

\begin{tabular}{|c|c|c|c|c|c|c|c|c|c|c|c|}
\hline Breeds of animal & No. & $\%$ & Breeds of bird & No. & $\%$ & $\begin{array}{l}\text { Size of } \\
\text { Livestock: } \\
\text { Cow }\end{array}$ & No. & $\%$ & $\begin{array}{l}\text { Size of } \\
\text { Poultry: } \\
\text { Chicken }\end{array}$ & No. & $\%$ \\
\hline Goat & 33 & 26.8 & Chicken & 71 & 57.7 & Below 10 & 8 & 6.5 & Below 10 & 3 & 2.4 \\
\hline Sheep & 6 & 4.9 & Duck & 6 & 4.9 & $11-20$ & 8 & 6.5 & $10-20$ & 48 & 39.0 \\
\hline Goats and Sheep & 55 & 44.7 & Chicken and Duck & 27 & 22.0 & $21-30$ & 5 & 4.1 & $21-30$ & 52 & 42.3 \\
\hline Goat and Cattle & 9 & 7.3 & $\begin{array}{l}\text { Guinea fowl and } \\
\text { Chicken }\end{array}$ & 2 & 1.6 & Above 30 & 6 & 4.9 & Above 30 & 5 & 4.1 \\
\hline \multirow[t]{12}{*}{$\begin{array}{l}\text { Goats, Sheep and } \\
\text { Cattle }\end{array}$} & 20 & 16.3 & $\begin{array}{l}\text { Guinea fowl, Chicken } \\
\text { and Duck }\end{array}$ & 7 & 5.7 & $\begin{array}{l}\text { Mixed } \\
\text { Goat }\end{array}$ & 96 & 78 & $\begin{array}{l}\text { Mixed } \\
\text { Guinea fow }\end{array}$ & 15 & 12.2 \\
\hline & & & & & & Below 10 & 14 & 11.4 & Below 10 & 1 & .8 \\
\hline & & & & & & $11-20$ & 82 & 66.7 & $10-20$ & 9 & 7.3 \\
\hline & & & & & & $21-30$ & 18 & 14.6 & $21-30$ & 10 & 8.1 \\
\hline & & & & & & Above 30 & 2 & 1.6 & Above 30 & 1 & .8 \\
\hline & & & & & & Mixed & 7 & 5.7 & Mixed & 21 & 17.1 \\
\hline & & & & & & Sheep & & & Duck & & \\
\hline & & & & & & Below 10 & 13 & 10.6 & Below 10 & 6 & 4.9 \\
\hline & & & & & & $11-20$ & 55 & 44.7 & $10-20$ & 14 & 11.4 \\
\hline & & & & & & $21-30$ & 8 & 6.5 & $21-30$ & 6 & 4.9 \\
\hline & & & & & & Above 30 & 7 & 5.7 & Above 30 & 2 & 1.6 \\
\hline & & & & & & Mixed & 40 & 32.5 & Mixed & 95 & 77.2 \\
\hline
\end{tabular}

Source: Fieldwork, 2018

\section{Involvement of rural women in various livestock and household activities}

The data on the extent of the involvement of rural women in livestock activities and household management as well as involvement indices and order of ranking is represented in Table 3. Information on livestock activities revealed that all the respondents were involved regularly in cleaning of animal sheds, watering and grazing of animals. These activities had involvement indices of 246 and ranked number 1 . Next in rank and participation indices were gathering of animal dungs, delivery assistance and animal health treatment. Table 3 further divulged that rural women in the study area occasionally partook in taking off grazing and sale of poultry and small ruminants. However, a greater proportion (above three - quarter) were not at all involved in milking of animals, preparing milk products, egg collection, barn preparation, sale of livestock, sale of eggs, milk and milk products. The preceding results portended that women in the study area performed most of the key livestock production and management activities. This is consistent with Tulachan and Karki, (2000) who acknowledged that among all the livestock production and management functions, women perform the most part of them. Regarding household activities, Table 3 disclosed that washing of clothes, food preparation, cleaning of the house, looking after all family members, child/family health care, preparing beverages and cleaning up after meals were undertaken regularly by women in the study area. 


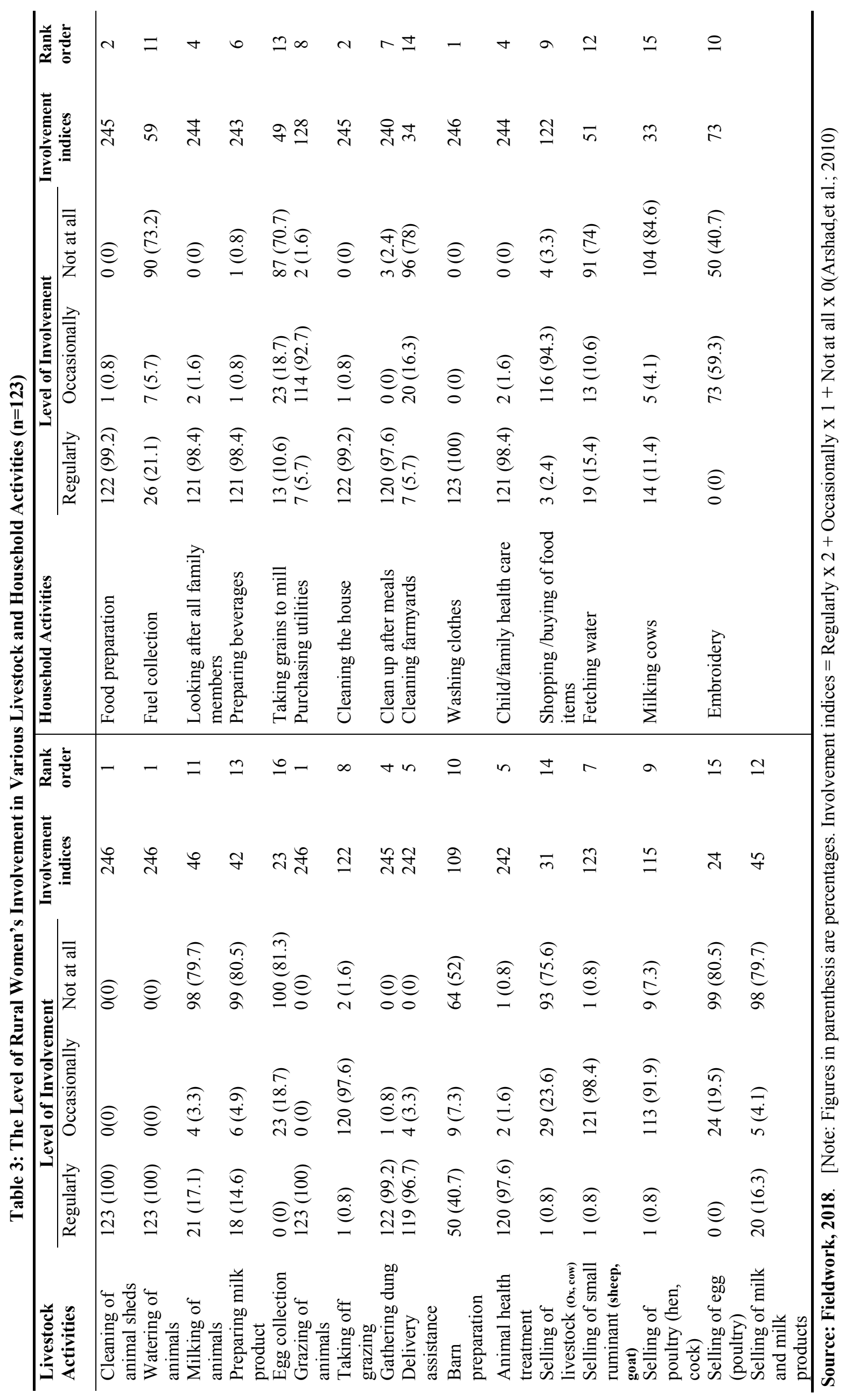


Occasionally, women participated in purchasing of utilities, embroidery and buying of food items, taking grains to mill, cleaning farmyard and fetching of water and have minimal participation in fuelwood collection. By implication, household activities not undertaken by women in the study area could be tasks considered by the community as works performed by men because of their strenuous and drudgery nature.

\section{Uses of income generated from livestock raising}

Information on the proceeds from livestock production by women, reasons for sale of animals and the peak season of sale were expressed in Table 4 . The data in Table 4 depicted that half $(50.4 \%)$ of the respondents generated between $\$ 10,000-\$ 20,000$ monthly from livestock activities. Next in percentage is 29.3\% ( $\$ 20,100-\$ 30,000$ ), 13.0\% (Above $\$ 30,000$ ) and $7.3 \%$ ( $\$$ 5,100 - $N$ 10,000) respectively. Approximately, three- fourth of the respondents sell animals to cater for health of family members, health of animals, ceremonies and educational needs. An overwhelming proportion (77.2\%) of livestock raisers reported that the peak seasons of sale were usually periods of ceremonies. These are times of the year in which demands for livestock are always above average and sellers could sell at suitable prices.

\section{Table 4: INCOME FROM LIVESTOCK AND POULTRY RAISING, PEAK SEASON AND REASONS FOR} SALE OF LIVESTOCKS $(\mathrm{n}=123)$

\begin{tabular}{lcc}
\hline Variable & Number & Percentage \\
\hline Income & & \\
$5100-10,000$ & 9 & 7.3 \\
$10100-20,000$ & 62 & 50.4 \\
$20100-30,000$ & 36 & 13.0 \\
Above 30,000 & 16 & \\
Reasons for Sale & & 73.2 \\
Health of family, health of animal, ceremonies and educational needs & 90 & 26.8 \\
Visits to other family members, replenishment of stock and disposal of & 33 & \\
sick animals & & \\
Peak Season of Sale & & 22.8 \\
Onset of farming season & & 77.2 \\
Ceremonies & 28 & \\
\hline
\end{tabular}

Source: Fieldwork, 2018.

\section{Challenges of livestock raising and household management}

Table 5 discusses data on challenges faced by women livestock raisers regarding livestock and poultry production, household management and sources of funding. It is evident from the table that low innovation (ranked 1), rustling (ranked 2), ranching (ranked 2) and health of animals (ranked 2) were reported as the major bottlenecks confronting livestock and poultry activities in the study area. Regarding household management, respondents stated that child/family care (ranked 1), food (ranked 1) and fuel wood collection (ranked 3) were core challenges facing women in Nafada LGA. Concerning availability of funding, family support is the only source moderately available for women livestock raisers. 


\begin{tabular}{|c|c|c|c|c|c|}
\hline \multirow[t]{2}{*}{ Challenge } & \multicolumn{3}{|c|}{ Level of challenges } & \multirow[t]{2}{*}{ Mean } & \multirow[t]{2}{*}{ Ranl } \\
\hline & High & Moderate & Not at all & & \\
\hline \multicolumn{6}{|l|}{ Livestock and Poultry Raising } \\
\hline Health & 3 & 118 & 2 & 1.0 & 2 \\
\hline Fodder & 3 & 100 & 20 & 0.8 & 5 \\
\hline Water & 0 & 9 & 114 & 0.1 & 7 \\
\hline Ranching & 1 & 119 & 3 & 1.0 & 2 \\
\hline Rustling & 1 & 119 & 3 & 1.0 & 2 \\
\hline Low Innovation & 121 & 1 & 1 & 2.0 & 1 \\
\hline Shed Improvement & 1 & 32 & 90 & 0.3 & 6 \\
\hline \multicolumn{6}{|l|}{ Household activities } \\
\hline Child/Family Health Care & 0 & 85 & 38 & 0.7 & 1 \\
\hline Food & 0 & 92 & 31 & 0.7 & 1 \\
\hline Water & 1 & 8 & 114 & 0.1 & 4 \\
\hline Fuel wood Collection & 3 & 19 & 101 & 0.2 & 3 \\
\hline Shed Provision & 0 & 3 & 120 & 0.0 & 5 \\
\hline \multirow[t]{2}{*}{ Sanitation } & 0 & 0 & 123 & 0.0 & 5 \\
\hline & Readily available & $\begin{array}{l}\text { Moderately } \\
\text { available }\end{array}$ & Not at all & & \\
\hline \multicolumn{6}{|l|}{ Sources of Funding } \\
\hline Government Agencies & 0 & 0 & 123 & 0.0 & 2 \\
\hline Non-Governmental Organization & 0 & 1 & 122 & 0.0 & 2 \\
\hline Cooperatives & 0 & 2 & 121 & 0.0 & 2 \\
\hline Family Support & 0 & 123 & 0 & 1.0 & 1 \\
\hline
\end{tabular}

Source: Fieldwork, 2018.

Note: Mean $=\underline{\text { High } \times 2+\text { Moderate } \times 1+\text { Not at all } \times 0}$

$\mathrm{n}$

\section{Association of social variables with women participation in livestock and household management}

The relationship between socio economic factors and women's involvement in livestock and household activities is displayed in Table 6. The involvement of women livestock raisers was significantly and positively associated with level of education $(\mathrm{p} \leq 0.01)$ and household size $(p \leq 0.01)$. This implies that the higher the level of education and family size the more the tendency to take the risk in livestock production, since the knowledge and family workforce will be there to help succeed. Similarly, Ayoade, Ibrahim and Ibrahim, (2009) and Furuta and Salway (2006) found a significant association between women's level of education and their decision making - ability in livestock production.

Table 6: Relationship between social variables and participation of rural women in livestock and household activities.

\begin{tabular}{llll}
\hline Independent variables & $\begin{array}{l}\text { Correlation coefficient } \\
\text { ('r' value) }\end{array}$ & Probability & Comment \\
\hline Education & 0.232 & 0.010 & Significant \\
Marital status & -0.139 & 0.125 & Not Significant \\
Marital union & -0.108 & 0.237 & Not significant \\
Household size & 0.272 & 0.002 & Significant \\
Joint Family Responsibility & 0.102 & 0.260 & Not Significant \\
& & & \\
Occupation & 0.040 & 0.663 & Not Significant \\
Income & 0.174 & 0.058 & Not Significant \\
\hline
\end{tabular}




\section{CONCLUSION}

It is apparently clear from the study that the women besides their major responsibility of household care regularly undertook major livestock raising activities. The men mostly performed activities that are generally hard natured and outside home activities. Participation of the women in poultry, goat and sheep production ranked greater than other forms of livestock raising due to lesser initial cost of investment. Socio- economic status of women livestock raisers vis-a-vis their level of education, income and family size determined the extent of their involvement in livestock management activities in Nafada LGA. Prominence of climate variability and change in the study area has greatly inhibited ranching (owing to expansion of farmlands), heightened cases of rustling and increased morbidity and mortality of livestock limiting women's engagement in livestock farming. In addition, inadequate funding and pre-occupation with household chores constrained women's degree of participation in livestock raising in the study area.

\section{RECOMMENDATIONS}

In view of the results of the study, the following policy implications are made:

i. Acknowledgement of women's economic contribution: Since, women are the main actors or contributors in livestock management and production related activities, their roles must be recognized and acknowledged by the government and non-governmental organization not only in the society at local levels but in national accounts as well.

ii. Transformation of societal norms: Government and other development actors are to devise and implement policies that would curb cultural, social, and economic factors inhibiting the development and productivity of women in most of our societies. This can be achieved through well-organized and integrated awareness creation strategies facilitated by stakeholders ensuring behavioral changes in the minds of people, especially males, creating equal opportunities of gaining access to education, health, and employment as well as building, incorporating, and streamlining the half of country's human resource into the national development process.

iii. Gender specific projects: Government and other institutions must identify the training needs of women livestock raisers and organize women-focused programs or projects to train them and to build their capacities in better and more profitable livestock farming. This would raise women's contribution to family and national income.

iv. Availability of funding: Government and other development institutions should ensure that women are linked with micro finance banks to have access to soft loans, which can be used to improve their participation and expand enterprises for greater income.

v. Breed Improvement: Development actors are to ensure introduction of more resistant breeds of animals at affordable prices to women livestock raisers in the study area.

vi. Increased Extension /Veterinary services: Extension/ Veterinary officers should arrange frequent and organized workshops for vaccination of flocks to minimize the rate of mortality and morbidity of animals.

\section{References}

Abdulhameed, A., and Onuk, E. (2016). Determinants of Women Participation in Livestock Production in Mangu Local Government Area of Plateau State, Nigeria. Scientific Papers Series Management, Economic Engineering in Agriculture and Rural Development, 16(3):135-138.

Afridi, G., Ishaq, M., and Ahmad, S. (2009). Estimation of Costs and Returns and Factor Productivity in Livestock Enterprise in Northern Areas, Pakistan. Pakistan Journal of Life and Social Sciences, 7(1),43-51.

Amin, H., Ali, T., Ahmad, M., and Zafar, M. (2010). Gender and Development: Roles of Rural Women in Livestock Production in Pakistan. Pakistan Journal of Agricultural Sciences, 47(1).

Aqeela, S., Tanvir, A., Munir, A., and Muhammad, Z. (2005). Gender Participation in Livestock Production Activities and their Consumption trend of Proteineous Diet in TEHSIL FATEH JUNG. Pakistan Journal of Agricultural Science, 42: 3-4. 
Dan, Y., \& Kim, I. (2020). Women Participation in Livestock Raising and Household Managemnt In Rural Communities of Nafada, Semi-Arid Region Of Northeastern Nigeria. Advances in Social Sciences Research Journal, 7(1) 166-177.

Arshad, S., Muhammad, S., Mahmood, A. R., and Khalid, M. (2010). Rural women's involvement in decision-making regarding livestock management. Pakistan Journal of Agricultural Science. , 47(2):1-4.

Ayoade, J., Ibrahim, H., and Ibrahim, H. (2009). Analysis of women involvement in livestock production in Lafia area of Nasarawa State, Nigeria. Livestock Research for Rural Development, 21(12), 1-5.

Azid, T., Aslam, M., and Chaudhary, M. (2001). Poverty, Female Labour Force Participation, and Cottage Industry: A Case Study of Cloth Embroidery in Rural Multan. The Pakistan Development Review, 40 (4):1105-1118.

Beth, A. (2001). Rights to Livestock Production.2020. Focus No. 06.Pp 1-4.

Dawit, T., Tadesse, D., Ahmed, Y., and Minilek, K. (2012). Extent of Rural Women Participation and Decision Making in Seed Production Activities. Global Advanced Research Journal of Agricultural Science , 1(7):186-190.

Furuta, M., and Salway, S. (2006). Women's Position within the Household as a Determinant of Maternal Health Care Use in Nepal. International Family Planning Perspective , 32(1), 17-27. .

IFAD. (2007). Women livestock managers in the third world: a focus on technical. Retrieved from http://www.ifad.org/gender/thematic/livestock/live_2.htm (5/11/2018)

Ogunlela, Y., and Mukhtar, A. ( 2009). Gender Issues in Agriculture and Rural Development in Nigeria: The Role of Women. Humanity and Social Science Journal., 4(1): 19-30.

Shafiq, M. (2008). Analysis of the role of women in livestock production in Balochistan. Pakistan Journal of Agricultural and Social Sciences, 4 (1), 18-22 .

Shephard, R. J. ( 1999). Age and Physical Work Capacity, Experimental Aging Research. Vol. 25, Issue 4.

Tulachan, M., and Karki, S. (2000). Gender and Livestock Management in Mixed Farming Systems. ICIMOD Newsletter, No.37.

Tusawar, I. (2013). The role of rural women in livestock management: socio-economic evidences from diverse geographical locations of Punjab (Pakistan. Geography. Université Toulouse le Mirail Toulouse II.

World Bank. (2003). Operationalizing Agricultural Extension Reforms in South Asia- A Case of Pakistan. Delhi, India: Country Paper: Regional Workshop. 